\title{
LITERATURE
}

\author{
@ \\ Katarzyna Biela \\ JAGIELLONIAN UNIVERSITY \\ K.BIELA@DOCTORAL.UJ.EDU.PL \\ HTTPS://ORCID.ORG/OOOO-OOO2-7392-2546
}

\section{B.S. Johnson's Liberatic Cityscape in Albert Angelo}

\begin{abstract}
For Bryan Stanley Johnson, a British post-war avant-garde author, space was a crucial aspect of a literary work. Inspired by architects and film makers, he was convinced that "form follows function" ("Introduction" to Aren't You Rather Young to Be Writing Your Memoirs) and exercised the book as a material object, thus anticipating liberature - a literary genre defined in 1999 by Zenon Fajfer and Katarzyna Bazarnik, which encompasses works whose authors purposefully fuse content with form. The goal of this paper is to analyse the cityscape theme in Johnson's second novel, Albert Angelo (1964), in which London is presented as space that accompanies the character in his everyday life and becomes a witness of the formation of his identity. The protagonist is an architect by profession, so special attention is paid to his visual sensitivity and the way the cityscape is reflected in his thoughts. Furthermore, Johnson's formal exploitation of the book as an object and its correspondence to the content is analysed with reference to the metaphor of "[t]he book as an architectural structure" discussed by Bazarnik in Liberature. A Book-bound Genre.
\end{abstract}

Keywords: B.S. Johnson, Albert Angelo, cityscape, liberature

\section{Architecture in B.S. Johnson's view and in liberature}

Bryan Stanley Johnson was a post-war British author who considered conveying truth to be one of his main goals: "I choose to write truth in the form of a novel" seems to be one of the statements that formed the basis for his works $(1973,14)$. This deci-

1 Research financed from the budget for science and arts 2018-2022 as a research project being a part of the "Diamond Grant" programme. 
sion implied that he could approach fiction with nothing but distance: "Telling stories really is telling lies" (ibid.) is his another famous quote and it might explain why he would often turn to his own experiences when searching for characters and inspiration for a plot ${ }^{2}$.

So concerned with his purpose, he would even go beyond his main occupation and admit that writers can (and should) learn a lot from people of different professions, especially film makers and architects (ibid., 11-16). Having noticed how quickly and directly a story can be presented on screen, he was convinced that the task of novelists is about much more than giving a description of events and satisfying the audience's need to know what comes next (ibid.). The way it is executed by means of the language, style and form chosen by a writer is of great importance:

the novel may not only survive but evolve to greater achievements by concentrating on those things it can still do best: the precise use of language, exploitation of the technological fact of the book, the explication of thought. Film is an excellent medium for showing things, but it is very poor at taking audience inside characters' minds, at telling it what people are thinking (ibid., 12).

Besides, writers should look up to architects whose projects ought to be aesthetically pleasing and functional at the same time. Johnson was concerned that writing is similar to designing buildings to a great extent, which can be seen in his approach to content. To him "[s]ubject matter is everywhere, general, is brick, concrete, plastic" and should be conveyed in a form that makes it possible to handle the messy and chaotic reality (ibid., 16-18). Significantly, he assumed that "[f]orm is not the aim, but the result" (ibid., 16), thus stressing that even the most radical and extraordinary ideas about exercising the book should not be art for art's sake, but justified and thought over projects that enable an author to express his message as precisely as possible. Such an approach to writing made him "unique in the decade, and indeed in his generation of post-war novelists, for the extent of his formal experimentation" (Jordan 2010, 102) since it let him view the novel not as a story and a narrative only, but rather as text rendered in a material, three-dimensional book.

No wonder then that Johnson's works have been also interpreted in the context of liberature - a literary genre defined in 1999 by Zenon Fajfer and Katarzyna Bazarnik, encompassing literary works in which authors purposefully use both content and form for their aesthetic purposes. As Bazarnik states, liberature "would denote a kind of creative writing that fuses text with its physical form into an inseparable whole in the space of the book" (Bazarnik 2016, 13). The fact that the name of the genre has its roots in the Latin word liber emphasises the importance of the book as an object, but

2 For instance, he arranged a voyage on a trawler to get material for his third novel, which tells a story of a man travelling on a ship and recollecting his past. See: Coe, Jonathan (2005). Like a Fiery Elephant: the Story of B.S. Johnson. London: Picador, 147. Print. 
also the liberty to make use of the opportunities and tools provided by its materiality (ibid.). Still, despite the attention paid to the (very often unconventional) form, "the unquestioned dominance of the literary component", i.e. text (ibid.), is crucial for the concept as illustrated in the close linguistic connection to the word "literature".

Johnson as well as Fajfer and Bazarnik see potential in the physicality of the book and share the belief that it should be consciously used. In fact, the latter have recognized Johnson's works as good examples of putting their concept into practice. In "A Brief History of Liberature," where they mention different writers who considered the form of the book meaningful, they admit that "[b]ecause of its consistently liberary $^{3}$ character, Johnson's work deserves special attention. Practically all of his works are characterised by a typically liberary attitude to the text, which subordinates the typography of the book to the demands of the text" $(2010,90)$.

What appears interesting in the juxtaposition of the two approaches is that similarities between them encompass also references to architecture. Johnson assumed writers can learn from architects, while the first academic publication on liberature, $\mathrm{Od}$ Joyce'a do liberatury (2002), was given the subtitle "Essays on the architecture of the word." Moreover, in "(N)on Description of Liberature" Fajfer supports his argument with the periphrasis: "[1]iberature or architecture of the word" $(2010,61)$, marking the importance of space in liberatic works, while Bazarnik in her analysis of conceptual metaphors in liberature refers to Johnson and describes him as "particularly relevant" in the context of one of them, namely "[t]he book as an architectural structure" (2016, 57). Later she draws on the blend "HOUSE = BOOK", which appears in N. Katherine Hayles's and Alison Gibbons's interpretation of Mark Z. Danielewski's House of Leaves, as well as George Lakoff and Mark Johnson's metaphor AN ARGUMENT IS A BUILDING (ibid., original captions). She arrives at the conclusion that "the metaphor implies that form is content, and content is form" and contends that B. S. Johnson was aware of this fusion "almost literally" (ibid., original emphasis).

Given the importance of architecture in Johnson's view on literature as well as in his work, the goal of this paper is to analyse how London is presented in his second novel, Albert Angelo (1964). The liberatic point of view will be of help to see how he employs the conceptual metaphor of "[t]he book as an architectural structure" (Bazarnik 2016, 57) in the context of the representation of the city. As Bazarnik discusses the relationship between the metaphor and Johnson's various narrative strategies in the novel (ibid., 57-62), it may be beneficial to explore further the relationship between content and form, focusing on the cityscape theme. This will provide an opportunity to examine how the protagonist's perception of the city corresponds with the meaningful shape of the volume.

3 The adjective referring to liberature was getting its shape as the concept has been developing. Two options were considered: "liberary" associated with "literary" to highlight the importance of the textual message and "liberatic" associated with "epic", "lyric" and "dramatic" to focus on liberature as a literary genre. Eventually, the former has been replaced by the latter, which is why I use the word "liberatic" both in the title and later, in the body of my article. 


\section{London in Albert Angelo}

Albert Angelo, published in 1964, is a story of a middle-class Londoner who dreams of architectural enterprises while working as a supply teacher. In the course of action readers get to know his profession, the school environment and his attitude to society, but also his private life, especially his relationships with parents, a friend and a girl with whom he had an affair. The story is presented by means of various literary styles as well as unusual typographical devices, e.g. double columns on a page and a hole in a few pages. Surprisingly, towards the end of the novel the story is rejected and labeled as unreliable for the reason that it fails to render what it was supposed to render. At the end of the third part entitled "Development" the choice of Albert as a fictional character turns out unsuccessful and the protagonist is killed. As Johnson admits nine years after the publication, Albert Angelo was the novel, with which he "broke through the English disease of the objective correlative" $(1973,22)$. In this way, the discussion on fiction and its limitations is also a crucial part of the whole narrative.

The importance of the cityscape theme, which is yet another key motif in the novel, can be seen in the very fact that the location of the main protagonist's house was chosen by Johnson with great consideration. It is meaningful in itself as it determines the character's identity and social status. As Andy Wimbush notes:

Albert is even named after his place in the city: 'Angelo' becomes his nickname after some of his unruly pupils find out that he lives in Percy Circus, in Islington, an address that, needless to say, was far less desirable in 1964 than 2013 (2013, para. 12).

Lawrence Phillips, who focuses on the representation of the city in the novel and analyses it as a "London narrative", approaches the significance of the area from a similar, negative perspective when pointing to "the crookedness of the Circus's state of repair, the rubbish and of course the bomb damage that has been patched-up" (Phillips 2006, 98). To his mind, the place is a symbol of London after World War II, the condition of the whole Britain and, eventually, Albert's condition with all "his emotional distress and physical decline patched-up much like the buildings" (ibid.). However undesirable, Percy Circus remains in the centre of the character's life and influences him to a great extent, further has a bearing on the structure of the novel. As Phillips contends, Albert Angelo is "increasingly a meditation on place and identity, and latterly on writing, narrative structure and art in which London as a social matrix, cultural nexus and physical presence becomes increasingly uncanny" (ibid., 91). A juxtaposition of three elements can already be traced in this quotation and it is made even more explicit in the course of Phillips's analysis as he seems to merge the narrative, the cityscape theme and the protagonist in the phrase "[t]he text/city/individual" (ibid., 99). The space where Albert carries out his actions is not only the geographical background in the story, but also a symbol of the character's social status, his state of mind and, as it appears in the end, the whole novel. It might be for Johnson's respect towards 
film makers that the locale is so carefully chosen and that it matches the protagonist's thoughts and actions.

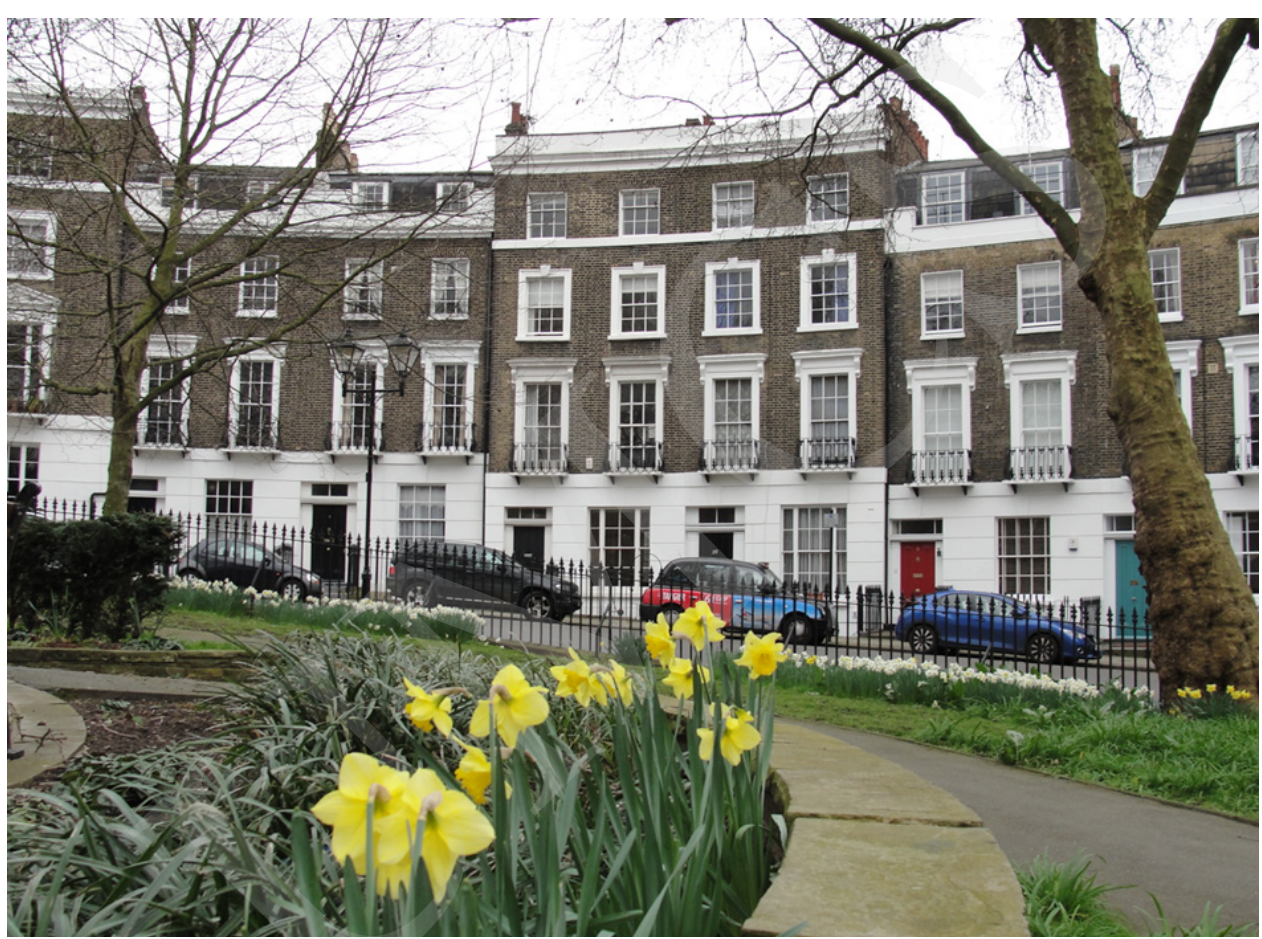

Percy Circus, London. Photo: Katarzyna Biela, 2017.

The streets that lead from Percy Circus in many directions determine Albert's walks, both those he goes for by the force of habit and the occasional ones. In fact, a considerable part of the novel is devoted to extensive, accurate and detailed descriptions of the protagonist commuting or strolling around London. Albert mentions virtually every street he passes, demonstrating his knowledge on famous architects and architectural styles. In fact, London is so precisely captured that one could use the novel as a map or a guide and follow the character's steps (See: Higden 2014, 244). The descriptions testify also to the character's passion for designing buildings and his true vocation. To use Wimbush's words, Albert "sees the city with an architect's eye" (2013, para. 11). This can be noted, for instance, in the account of his way to the King's Cross station, where every Saturday he takes a train to visit his parents at Hammersmith:

I walk down the hill from Percy Circus, along Kings Cross Road, into Pentonville Road, towards Kings Cross. The station has two great squat stock-brick arches, their yellow un-

4 I took a similar walk, following the places mentioned in the novel, in 2017. 
commonly unblackened; Cubitt, the youngest, Lewis. Then there are the pseudo-Gothic excrescences of Scott's St. Pancras. I wonder shall I come to accept St. Pancras station, living so near? Or even to like it? Perhaps it is fatal to live so near to St. Pancras for an architect? Certainly it would be to bring up children here: their aesthetic would be blighted. But it seems unlikely that I shall be allowed to bring up children here.

Kings Cross is crowded, the tube station, with non-Londoners, foreigners, who do not know their ways, upfortheweekenders who stand on both sides of the escalator with too much luggage and go as far as Picadilly (Johnson 2004, 20).

Such a careful observer as Albert cannot miss the buildings that are damaged or do not match their surroundings. His taste is sophisticated and that is why at times he must give vent to his dissatisfaction with poor style and the inconveniences of life in the city. The description appears timeless for, as Wimbush sarcastically states, "[e]ven... if today's Londoners have rehabilitated some of the buildings that Albert scorns, his irritation with 'non-Londoners' on the tube is still keenly felt" (2013, para. 12). The passage demonstrates also that the character feels displaced in his surroundings and his sense of belonging suffers terribly, which seems even more pessimistic if we bear in mind that St. Pancras is close to his home and that he passes it regularly. Contact with the buildings in this case makes him ask rhetorical questions about the future and ruminate on his difficult situation as if he was anticipating the question his mother is going to ask when he arrives: "Why don't you take a permanent job, Albert?" (Johnson 2004, 23).

Another instance of Albert describing a route he has taken is when he recollects a date with his ex-girlfriend, Jenny:

He walked with her, she walked with him, along Picadilly, down Lower Regent Street, through the Palladian-Greek vista formed by Smirke's Royal College of Physicians, Wilkins' National Gallery, and Gibbs' St. Martin's-in-the-Fields. Then he showed her Hungerford Lane, under the rsjs, past the doorways of arch-lockups, the several smells of various different storages, and the roofline through the gap up to the right like a random clerestory mullioned by fire escapes and black leaning stacks: and where he would have kissed her, there in the winedark shadows beneath the groined arches before they turned out through the garage into Villiers Street, but for his need to do it so anti-romantically, to prove it, the romance, the love. So he waited until they were in the well-lit vaulted approaches to the footpath of Hungerford Bridge, and then in the middle of the sentence... (ibid., 49).

The account begins with an enumeration of streets and buildings that appear to be purposefully chosen by Albert to impress his beloved. This part of London seems more pleasant to be in, but, nevertheless, the mood of its description gets more and more negative and the choice of "the well-lit vaulted approaches to the footpath of Hungerford Bridge" (ibid.) as a spot for a kiss might be regarded as a foreshadowing of the couple's parting a few sections later. 
Yet another example is the account of the time Albert spends with his friend, Terry, after work:

\begin{abstract}
Most usually we head down City Road, then sharp left at Old Station, bear right into Great Eastern Street and Commercial Street, down to Whitechapel. Sometimes we stop there at Aldgate for cockles or prawns at Tubby Isaacs', but more often we will go straight on down to Cable Street, and Terry will park this Fiat he runs in Wellclose Square.

Visually, architecturally, Cable Street, Cablestrasse, The Strasse, at night excites us: everywhere we go in this part of Stepney there are Georgian façades in all stages of repair, from the one beautifully kept house in Wellclose Square to others with skeletal dormers from which the lead and boards have been stripped. There are bomb-derelict warehouses, too, one with a thick first-storey drawbridge suspended from chains above the gulf (ibid., 51).
\end{abstract}

This route is very long since Albert and Terry treat it as a peculiar cure for their heartbreaks and problems at work: "Anyway, we talk, we listen and watch, several nights a week. [...] And to all sort of other places we go on these nights journeys, for all sorts of reasons, or non-reasons, or for no reasons [...] to save the loneliness, the oneness, of being in bed alone at night, for each of us" (ibid., 52-53). The walk gives them the opportunity to talk their misfortunes over and, significantly, the streets they walk along are of great historical and social significance. The Cable Street might remind them of the riots in 1936 - conflicts involving Sir Oswald Mosley's Union of Fascists, the anti-fascist groups and the police who tried to uphold order (See: Phillips $2006,94)$ - revealing the face of London as "a place of yawning gulfs between rich and poor, and of political strife" (Wimbush 2013, para. 13). The area matches their feeling of abandonment also because "they face the diasporic realities of another form of alterity, the colonial (or postcolonial) presence in the underprivileged quarters of London of Cypriots, West Indians, and Africans, among others" (Tew 2002, 24). Plurality is a significant feature of the city, which, as Phillips suggests, makes it difficult to understand the dynamics of the place and might even lead to fear $(2006,95)$. He also remarks that Albert's preference for Georgian architecture, noticeable in the first and the third passage I have quoted, illustrates that he is trying to go against the incomprehensible and "is actively seeking order, form, understatement and, perhaps, conformity" (ibid., 94).

The juxtaposition of multiplicity with Albert's eagerness to organize it alludes to the paradox of chaos and order, which Johnson mentions in his theoretical writings and explores in his literary works. As he states, "what characterizes our reality is the probability that chaos is the most likely explanation; while at the same time recognising that even to seek an explanation represents a denial of chaos" (Johnson 1973, 17). He believes that writing is an attempt to make sense of reality, even if actually this cannot be ever achieved. Such authorial reflections seem to be projected onto Albert's connection to the city and the cityscape theme: on one hand the descriptions of London demonstrate the character's "desire for structure" (Phillips 2006, 93) since they are so extensive, precise and detailed that it is difficult to imagine delivering them in a more 
orderly manner, but on the other hand they reflect conflicts of the society as well as the protagonist's inner struggles concerning his profession, relationships and social position. Paradoxically again, the accurate descriptions can be viewed as an anti-structural device since they seem to foreshadow the failure of the story that comes towards the end of the novel. It is questionable whether a description of a route in London that makes it possible to follow the fictional character in reality can be called "fiction". Wimbush treats "Johnson's slavish attention to London's geography" as a "reason why the label of 'fiction' fails us" (2013, para. 12). Therefore, "[t] he novel, the individual and the city are [...] in a process of perpetual dis/integration" (Phillips 2006, 97). The novel is being written, the identity of the character is being established, the 'fictional' city is being built, but at the same time all of them are being deconstructed and, in the end, torn into pieces when labeled as unsuccessful. Hence, Albert Angelo presents an example of creation that is simultaneously its own destruction.

\section{The windows and the columns}

The cityscape theme is crucial for the content, but it also matches Johnson's careful use of the book and its physicality. The author admits that in the novel "there were devices used to solve problems which I felt could not be dealt with in other ways" (Johnson 1973, 22-23). Capturing the paradox of chaos and order could potentially be one of these challenges. The most untypical exercises executed on the conventional shape of the book in Albert Angelo are presumably the columns in the description of Albert's geology lesson and the holes in the thirteenth part of "Development", which give the reader access to three lines from the fourteenth section before she actually reaches it. As Colin Burrow puts it, they make it possible to "to read a passage from the novel's future" (2013, para. 14).

Significantly, the reference to the cityscape theme can be considered straightforward in both of the devices, for the columns on a page may resemble columns used to support a building and the holes may be viewed as windows (See: Phillips 2006, 97 and Bazarnik 2016, 61-62). Still, similarly to the representation of the city in the content, the devices seem to have also metaphorical connotations, this time on the material and multimodal level. When Gibbons analyses Mark Z. Danielewski's House of Leaves as a work employing the metaphor "HOUSE=BOOK," she explains that

[t]he emergent blend [...] sees the book taking on properties of the HOUSE domain, such as corridors, doorways, windows, and so forth. The blend is achieved multimodally, in that these corridors and doorways are created through the diagrammatic organisation of text upon the page, their visual shape and layout producing an abstract, structural analogy of HOUSE $(2012,66)$. 
The columns and windows in Albert Angelo justify Bazarnik's choice of Johnson as a prominent writer with regard to the conceptual metaphor " $[t]$ he book as an architectural structure" $(2016,57)$ since his exploitation of the material shape of the volume demonstrates his awareness of such a metaphor governing cognition. Reading the novel lets not only accompany Albert during his 'fictional' walks around London, but also interpret the cityscape theme in the physical contact with the book. As Bazarnik remarks with reference to the holes, the reader "is made acutely aware of the constructedness of Johnson's work, of its concreteness, its objecthood, of the material reality that she is holding in her hands," (ibid., 61), which becomes even more explicit if we bear in mind that the passage she is encouraged to read three times describes a mortal wound and, hence, hints at physicality and flesh. On the other hand, though, the same device points to the "physical fracturing of the narrative continuity" (Phillips 2006, 97) since it results in a break-up of a page, a temporal distortion, the incongruity of the text that becomes "a patchwork of different texts" (Bazarnik 2016, 62) and, to use Glyn White's words, "the reversal" or even "the defeat of expectations" readers have when they take a book and are not yet aware of its untypical shape $(2005,103)$. In this way, the hole simultaneously reminds the reader of the materiality of the book, but also demonstrates the physical damage carried out on the traditional volume.

Likewise, the tension between construction and deconstruction applies to the columns, which illustrate the dialogue between the teacher and the students, visible on the left side of a page, as well as Albert's internal monologue presented in italics on the right. The columns foreground the physical shape of the novel, but also the simultaneity of the characters utterances, thus creating a truthful image of the classroom chaos. On the other hand, though, they illustrate how Johnson parts with the conventional look of the page and creates a challenge for readers who have to think of their own way to comprehend the text that is arranged in such a complicated way. When he himself comments on the device, he admits that "though the reader obviously cannot read both at once, when he has read both he will have seen that they are simultaneous and have enacted such simultaneity for himself" (Johnson 1973, 23). Hence, the columns contribute to the construction of the story, but simultaneously make it more difficult to comprehend it.

Overall, it seems that Johnson's usage of the metaphor of the book as a building is closely connected to the representation of the city in the content since the paradox of the creation leading to its own destruction is characteristic also for the material space of Albert Angelo. Therefore, when we think of Phillips's assumption that "[t]he novel, the individual and the city are [...] in a process of perpetual dis/integration" $(2006,97)$, we should take into consideration "[t]he novel" as book ${ }^{5}$ because the plot and the narrative go along with the physical shape of the book, testifying to Johnson's exploitation of "the conceptual metaphor of the story as a crumbling building" (Bazarnik 2016, 60).

I borrow this phrase from the title of Grzegorz Maziarczyk's book, The Novel as Book (Lublin: Wydawnictwo KUL, 2013). As he admits, a similar phrase appears in the title of Danuta Danek's Dzieło literackie jako książka [The literary work of art as book] (Maziarczyk 2013, 19). 


\section{Yet another thematic dimension?}

The analysis of the cityscape theme in Albert Angelo begs the question whether it is a coincidence that the city plays such a significant role in the novel of the author, who did not hesitate to make use of the physical aspects of the book. Johnson believed he can learn a lot from architects as a writer and treated his subject as "brick, concrete, plastic" $(1973,16)$. Whenever he decided to exercise the book as a material artifact, his action was purposeful and thought over: "Where I depart from convention, it is because the convention has failed, is adequate for conveying what I have to say. [...] So for every device I have used there is a literary rationale and a technical justification" (ibid., 19). Given that the cityscape is one of the crucial themes in Albert Angelo and that he paid so much attention to the truthfulness of his literary representations, it seems no wonder that he resorted to "[t]he book as an architectural structure" and is described as "particularly relevant" in the context of this conceptual metaphor in liberature (Bazarnik 2016, 57). Bearing in mind that, as Bazarnik explains, "cognitive analysis reveals how a sense of object's material substance is bound up with the conceptual metaphor of the literary work as a work of architecture" and that "the architecture of the book, i.e. its compositional space, functions as another important semantic mode operating along with the linguistic mode" (ibid., 65, 99), it would be justifiable for Johnson to use the material aspects of a book in order to extend his repertoire of literary tools and make his representation of the city even more accurate.

Another argument for Johnson's conscious implementation of the theme is that he resorts to it also in his other works. As Krystyna Stamirowska states, his "conspicuous references to buildings and architectural features in general, which are to be found in all his novels, are not contingent" $(2006,86)$. In his fourth novel, The Unfortunates, for instance, the narrator travels to Nottingham to write a report about a football match and, upon arrival, realizes that he knows the city because he used to spend time there with his friend, Tony, who died of cancer. The reader accompanies the narrator from the moment he leaves the railway station, until he catches his train back home. Throughout the journey, the city structures his memory retrieval as he keeps reminding himself of different events he took part in with his friend. The novel has been designed as a bookin-a-box to physically represent the chaos of memories and Tony's fragmented body.

In Liberature. A Book-bound Genre Bazarnik presents liberature as a literary genre with reference to i.a. John Frow's "structural dimensions", namely "the formal organization of genre," the rhetorical structure," and "the thematic content" (ibid., 135). In relation to the third one she gives a number of topics that are frequently addressed in liberatic works, these being: "the expressive potential of "the word'," "the book," "non-verbal aspects of the oral performance of language: gestures, pitch and tone of voice, facial expressions and the like," "representations of the mind, mental processes, and various, often altered states of consciousness," "a traumatic event or experience," "[t]he potential of posttraumatic growth, regeneration, and [...] re-genrification" and "a transformation" (ibid., 138-143). Given that Frow refers to the thematic dimension 
as "the shaped human experience that a genre invests with significance and interest" (ibid., 136), architecture could be perhaps suggested as yet another thematic dimension of liberature. The example of Johnson's demonstrates that an author whose aim is to create a literary representation of architecture might be willing to resort to the book as a material artifact on the basis of cognitive studies and the conceptual metaphor of the book as a building. Especially that, as Johnson demonstrates, the representation of cityscape may be closely connected to a protagonist's internal life - their memories, worldviews and traumas - that is themes which have already been included in the list of thematic dimensions of liberature.

Architecture as a potential thematic dimension of liberature seems worth further exploration also because, apart from Johnson, a number of other authors draw on buildings and cityscape in their liberatic works. For instance, a window as a surface symbolically marking the boundary between a room and the outside world, is a recurring image in Zenon Fajfer's poetry collection Widok z glębokiej wieży (View from the Deep Tower, 2015). Suggesting different ways of perceiving reality as well as transgressing the established and commonly known dimensions, such as depth and height, Fajfer presents also different perspectives on poetry and reading i.a. by complementing the verbal message with two photographs of windows and incorporating a spread of five unfolding pages in the poem meaningfully entitled "Balkon" ("The Balkony", ibid., 50-51). Radosław Nowakowski, in turn, represents cityscape in Ulica Sienkiewicza $w$ Kielcach $=$ Sienkiewicza street in Kielce $=$ Sienkiewicza strato en Kielce (2003) inscribing the handwritten text around drawings of buildings on a sheet of paper that is more than ten meters long. The shape of words as well as their distribution illustrate i.a. the pace of the character's walk. Not to mention Joyce's Ulysses, one of the most important works in the history of liberature, "which closely traces the wanderings of Bloom and Stephen across the Dublin Joyce grew up in" (Ryle 2014, 112).

\section{References}

Bazarnik, Katarzyna. 2016. Liberature. A Book-bound Genre. Kraków: Jagiellonian University Press.

Burrow, Colin. 2013. "Fetch the Scissors." London Review of Books 35 (7): np. https://www.lrb. co.uk/v35/n07/colin-burrow/fetch-the-scissors.

Fajfer, Zenon. 2010. Liberature or Total Literature. Collected Essays 1999-2009. ed. and transl. Katarzyna Bazarnik. Kraków: Korporacja Ha!art.

Fajfer, Zenon. 2010. “A Brief History of Liberature (with Katarzyna Bazarnik).” Liberature or Total Literature. Collected Essays 1999-2009. ed. and transl. Katarzyna Bazarnik. Kraków: Korporacja Ha!art.

Fajfer, Zenon. 2010. “(N)on Description of Liberature.” Liberature or Total Literature. Collected Essays 1999-2009. ed. and transl. Katarzyna Bazarnik. Kraków: Korporacja Ha!art. 
Fajfer, Zenon. 2015. Widok z głębokiej wieży. Szczecin: Wydawnictwo Forma: Fundacja Literatury imienia Henryka Berezy.

Gibbons, Alison. 2012. Multimodality, Cognition, and Experimental Literature. New York, London: Routledge.

Higden, David Leon. 2014. "B. S. Johnson's Albert Angelo as a Postmodern Counterbook." BSJ: The B.S. Johnson Journal. ed. J. Darlington, M. Hooper, M. Seddon, P. Tew and K. Zouaoui: 5-45. https://books.google.pl/books?id=pThPBwAAQBAJ\&dq=b+s+johnson+1 ove \&hl=pl\&source $=$ gbs_navlinks_s.

Johnson, Bryan Stanley. 2004. Albert Angelo. B. S. Johnson Omnibus: Albert Angelo; Trawl; House Mother Normal. London: Picador.

Johnson, Bryan Stanley. 1973. "Introduction." Aren't You Rather Young to Be Writing Your Memoirs? London: Hutchinson.

Jordan, Julia. 2010. "“Let's Celebrate the Accidental': B. S. Johnson, the Aleatory and the Radical Generation." Chance and the Modern British Novel: From Henry Green to Iris Murdoch. London: Continuum.

Maziarczyk, Grzegorz. 2013. The Novel as Book. Lublin: Wydawnictwo KUL.

Nowakowski, Radosław. 2003. Ulica Sienkiewicza $w$ Kielcach $=$ Sienkiewicza street in Kielce = Sienkiewicza strato en Kielce. Bodzentyn: Liberatorium.

Od Joyce'a do liberatury: szkice o architekturze słowa. 2002. ed. Katarzyna Bazarnik. Kraków: Universitas.

Phillips, Lawrence. 2006. London Narratives: Post-War Fiction and the City. London, New York: Continuum.

Ryle, Martin. 2014. “'Educated and intelligent, if down-at-heel': John Wain's Hurry On Down and B.S. Johnson's Albert Angelo." B. S. Johnson and Post-War Literature: Possibilities of the Avant-Garde. ed. Martin Ryle and Julia Jordan. Basingstoke: Palgrave Macmillan.

Stamirowska, Krystyna. 2006. B. S. Johnson's Novels: a Paradigm of Truth. Kraków: Towarzystwo Autorów i Wydawców Prac Naukowych Universitas.

Tew, Philip. 2002. "B. S. Johnson.” Review Of Contemporary Fiction 22 (1): 7-52. MLA International Bibliography.

White, Glyn. 2005. Reading the Graphic Surface: the Presence of the Book in Prose Fiction. Manchester, New York: Manchester University Press.

Wimbush, Andy. 2013. “B. S. Johnson: ‘Albert Angelo' - 1964.” londonfictions.com. Accessed June 13, 2019. https://www.londonfictions.com/bs-johnson-albert-angelo.html. 